\title{
The Popularization of Gugak: A Case Study of the MIJI Project, a Gugak Girl Group
}

\author{
Inhwa So \\ Busan National Gugak Center, South Korea \\ soinhwa@gmail.com
}

\begin{abstract}
As an aspect of cultural policy, the Korean government has made efforts to popularize Korean traditional music, gugak ("national music"). One way of doing so has been to offer financial support for gugak groups. MIJI, a gugak girl group, is one of the beneficiaries of this support. On the basis of the government funding, in 2008 the LOEN Entertainment Company began to manage the group in 2008. However, in 2010, the group was considered unsuccessful in achieving its original goal of providing a successful model of a gugak band by the scheduled year, 2011. In 2012, the group nevertheless became active again. An analysis of the project and its processes reveals the present situation of gugak in Korea and the problems involved in its popularization. Furthermore, through this process we are able to gain insights into the role of the Korean government in the promotion of gugak, through the long-term measures the government can take to popularize gugak; for example, by developing projects to connect performing music artists with the pop industry in a sustainable way, by increasing gugak programming in mass media and by strengthening gugak education in school.
\end{abstract}

KEYWORDS: gugak, government, Korea, popular music, MIJI

\section{Introduction}

Korean traditional music, or gugak ("national music"), is not popular among the general public in Korea. The main reasons for this are related to the country's recent music history of colonization and modernization. With the introduction of 
Western music in the $19^{\text {th }}$ century, Western music came to dominate the preferences of the upper classes and even became regarded as the only meaningful form of music, while indigenous music was regarded as the music of the lower classes. Throughout the Japanese colonial period (1910-1945) and the Korean War (1950-1953), the majority of Korean popular music demonstrated strong Japanese and Western influences.

After the Japanese occupation of Korea ended, mid-twentieth century, Korean governments made several attempts at reviving and preserving gugak as a way to re-establish Korea's national identity. Previous governments, ${ }^{1}$ from the first republic of 1948 till present, promoted traditional performing arts in their cultural policy. There was increased interaction between the government and the people related to gugak, such as musicians and producers, in order to emphasize the cultural value of gugak as one of the fundamental traditions of grass roots Korean culture. In 1962, the government established the Intangible Cultural Property System for the preservation of cultural heritage, such as gugak. Also, in response to the demand from gugak practitioners, the government gradually increased coverage of gugak songs in primary school music textbooks, all of which are designated by the government. This accounted for a total of $40 \%$ of the content of the music textbooks for first and second year classes in 1997 (So 2008: 912).

In response to increasing globalization during the 1980s, a process that accelerated musical exchange across national borders, the Korean government expanded its cultural policy to include all forms of popular culture to its already extensive programs in the preservation of traditional culture (Yim 2002: 47). The government began to pay more attention to the economic value of culture and arts, especially when the popularity of Korean popular cultural products started to surge in Asia during the late 1990s. Korean popular music (called K-pop in Western countries), together with Korean drama and movies, was one of the main elements of hallyu ("the Korean Wave").

In 2006, seeking to expand hallyu in a sustainable way, the Korean Ministry of Culture, Sports, and Tourism supported the development of the HanStyle ${ }^{2}$ in six fields: Korean language, food, clothing, paper, housing, and music (gugak), which were regarded as essential to traditional culture. These fields were found lacking in self-dependency and, thus, in need of strategic support (Um 2008: 474-475). The Korean government started to promote gugak as one of the six fields, with a focus on traditional forms of music and more contemporary versions (Korean Ministry of Culture, Sports and Tourism 2008: 175). It provided lavish funding for festivals of fusion gugak in which gugak is often blended with Western classical and popular music, to keep traditional music alive and to create cultural products for commerce (Sutton 2011: 17). Gugak FM, a radio station promoted by the Korean Ministry of Culture, Sports and Tourism, was established in 2001 in order to spread gugak. The station played not only traditional gugak but also fusion gugak with the primary aim of popularizing gugak. These projects, which attempt to globalize and commodify gugak as a product, manufactured for both domestic and international consumption, have become part of the government's agenda.

One example of these projects aimed at popularizing gugak among younger generations was the MIJI project wherein the government provided support for a gugak girl group, called MIJI. The members had previously been trying to join the ranks of K-pop; LOEN Entertainment, a company that was also involved in K-pop, 
took on management of the group in 2008 (Korean Ministry of Culture, Sports, and Tourism 2009: 28). However, the MIJI project ended in 2010 when the Ministry of Culture, Sports, and Tourism decided to stop supporting the group and the management company dropped them. It seemed that the group was doomed. However, in 2012, after a long break, the group came to be managed by a new entertainment company and became active again with a variety of performances including an appearance on a popular music TV show on MBC, one of Korea's main TV networks. By 2014, MIJI appeared on Star Avenue, one of the most popular entertainment programs of CCTV (China Central Television; Lee 2014).

The story of the government-initiated MIJI project shows the current state of gugak, which, while not commercially of high value or an easily distributable commodity, remains "an agent of state hegemony" (Howard 2008: 361). This project also shows the dilemma faced by young gugak musicians in transculturation as Korea grapples with "the tension between past and present" (Bhabha 1994: 175). For the purpose of this discussion, I follow Kartomi's approach to musical transculturation, which refers to a process of musical transformation by intercultural contacts (Kartomi 1995: 233). A dilemma is presented in the current state of Korean traditional music and its ongoing process of musical transformation caused by intercultural contact with the West, because in the process of musical transformation, gugak receives official support as a symbol of national identity within a post-colonial capitalist state dominated by Western culture and in the shadow of colonialism.

This article will analyze the government-supported project that connects gugak musicians with the popular music industry. It does so through interviews with the directors of MIJI, an MBC TV producer and MIJI band members, as well as other relevant musicians and officials. In addition, through a focus on the MIJI project, it is possible to address the problems involved in the popularization of gugak. Finally, the project is evaluated as a short-term measure to support popularization of gugak. On the basis of this analysis, several long-term solutions are suggested in the context of further governmental support.

\section{The formation and activity of MIJI: Gugak girl group}

Park Seung-won was the mastermind behind the formation of the MIJI group in 2008. After majoring at university in piri (a double reed wind instrument, like an oboe, but made of bamboo) Park started to work for LOEN Entertainment (formerly Seoul Records) in 1994. LOEN is one of the largest record companies in Korea. He was in charge of recording not only gugak but also pop music. In my interview with him (2011), Park said that while working at LOEN, he realized how small the gugak market was compared to that of pop music. He then decided to promote and sustain gugak within the popular music industry. Later, as a director of the gugak division, he applied for government funding for the so-called Star project. $^{3}$ Since no gugak performer was widely known through Korea, the Star project aimed at developing a gugak star group for the popularization of gugak. The Star project came to be also called as the MIJI project, whereby MIJI refers to "being unknown" in Korean. Shin Yong-ho (2010) reports that in September 2008, through a complex auditioning process, seven members were selected. Between 
them, the group members played both the traditional 12-stringed gayageum (long zither) and a modified 25-stringed gayageum, as well as a piri, a daegeum (large transverse flute), a sogeum (short transverse flute), and a haegeum (two-stringed fiddle). One year later, in October 2009, a female vocalist, named Kim Bo-seong, joined the band. After joining the team, the members received rigorous musical training to enable them to play Western style popular music on their Korean traditional musical instruments. No Korean traditional percussionist joined the group; instead, to provide stronger rhythmic impact, a Western-style drum set was invited.

The music of MIJI was composed for both Korean traditional and modified musical instruments. However, the group made use of Western tuning rather than traditional tuning. Park Seung-won (2011) believed that use of melodies based on the traditional gugak scale would present difficulties in moving listeners emotionally, since they are not yet sufficiently familiar with their own traditional music. His idea was similar to Kartomi's assumption that, in musical transculturation, it is even harder for an intangible musical scale to transcend historical and cultural boundaries than it is for the musical instruments, as tangible objects, to do so (Kartomi 1981: 244).

LOEN Entertainment arranged for popular music composers such as Lee Ji-soo and Jo Young-soo to work with MIJI. Lee was the music director for the TV drama series Winter Sonata, which became a great hit and an important factor in the spread of the hallyu ("Korean Wave") across Asia, and for successful movies including Lady Vengeance, Old Boy and Silmido. Jo has composed for such hallyu stars as SG Wannabe, Shinhwa and Lee Seunggi. By employing composers who had previously successfully composed music for hallyu products shows the influence of hallyu on MIJI (Sung 2009: 47). This differentiates MIJI from other fusion gugak groups such as Gong Myoung ${ }^{4}$ and Sangsang, ${ }^{5}$ whose members often compose their own music (Lee 2003: 193).

In December 2009, MIJI's first album, The Challenge, was released with ten tracks of instrumental music, and two ballad-style songs titled "Heunoni" and "Ibyeorae". The music employs a variety of elements, including Western music styles, such as jazz, tango and pop ballads, played on both Korean traditional musical instruments and Western orchestral instruments, which were added during the recording process. The titles of seven of the twelve tracks are in English. They can be grouped into two categories based on the songs' themes. One category is a dynamic and idealised image of Korea evoked through a combination of the unique tone color of Korean traditional instruments, upbeat rhythm of Western percussion, and the sustaining sound of a synthesizer, as in pieces like "K.new", "The Chaser", "Chowoneui Baram" ("Breeze in the Field"), "Vivid Rainbow", and "Silver Sky". The theme of the other category is romantic love and heart-breaking farewells, as in songs such as "Heunoni" ("Longing for Someone"), "Geuriumi Gipeoseo" ("Deep Nostalgia"), "Love Letter", "Ibyeorae" (or "My Farewell Comfort"),6 "Romantic Tango", and "Valediction". The final piece, an exception from the pop hybrid style, is an instrumental work with a light melody and rhythm which is an arrangement of the anonymous folk song "Gunbam Taryeong" ("Roasted Chestnuts Song") from the early twentieth century. 
FIGURE 1: A photo of MIJI for press release (Kang Young-ho 2009).

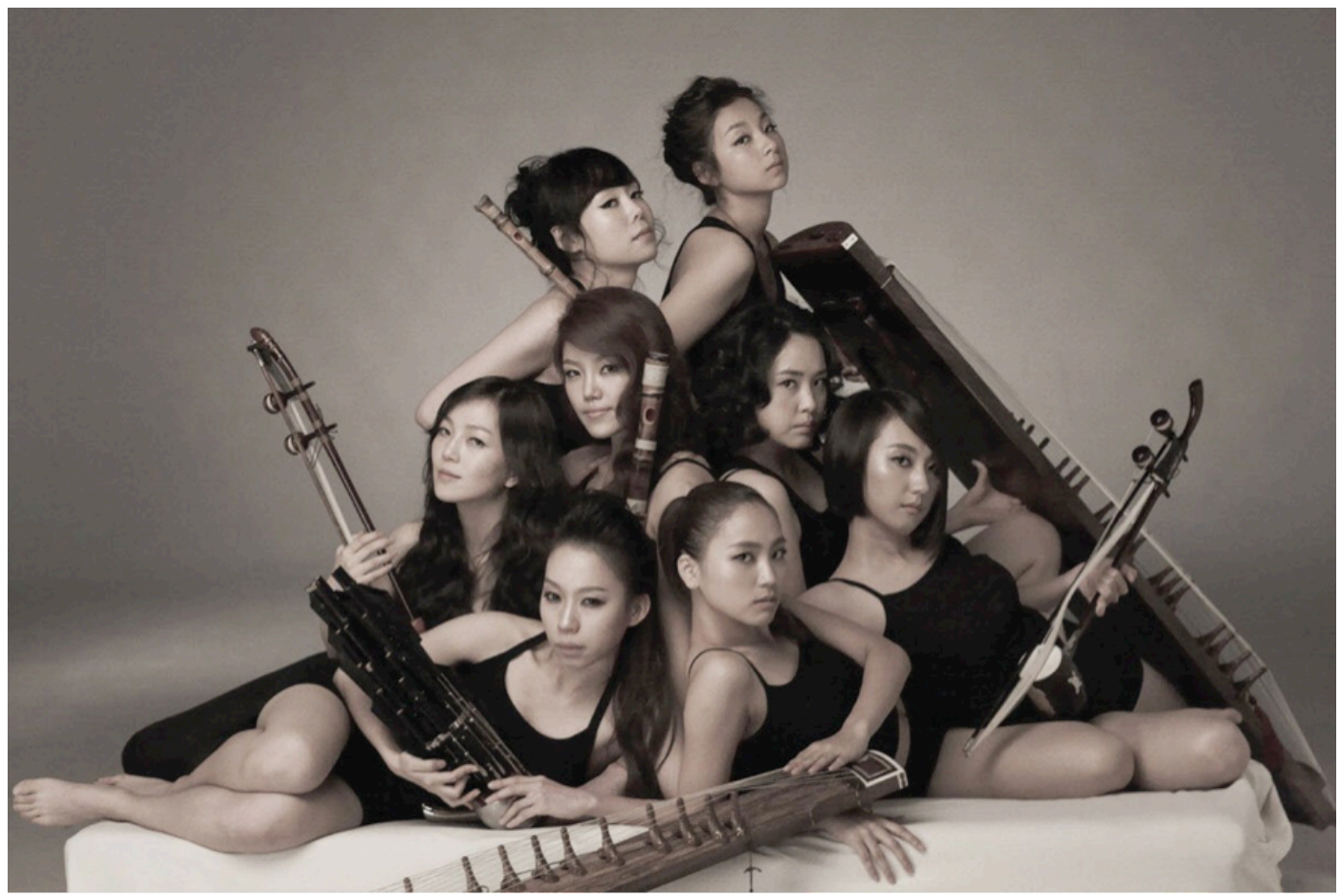

Im Jin-mo, a popular music critic (LOEN 2010: 21), holds a positive opinion of the MIJI album as a new hallyu brand. He focused particularly on three pieces from this CD. One was "The Chaser", in which the sound of Korean instruments was prominent in spite of being accompanied by the Western orchestral sound of the Czech Philharmonic Orchestra; another was "Geuriumi Gipeoseo", which he described as "deeply sad which is typically Korean". And the third was "Heunoni", which, like K-pop, is a vocal piece. Im believes that today people need to recognize not only the musicians of traditional gugak but also those of new or pop gugak (Gugak FM 2012). It should not be a matter of either traditional gugak or new gugak as both are needed for the diversity of gugak. According to Im, new gugak can be interpreted as an enrichment of traditional gugak preservation; as Bruno Nettl (1983: 346) states, new music of the world is constantly undergoing change through international interaction.

By contrast, Hahn Dong-yun, a popular music critic and selection committee member for the Korean Pop Music Awards, has criticized MIJI for not bringing more traditional music into their playing and for limiting themselves to mostly Western-influenced Korean popular songs. In his blog, he complains that MIJI is not concerned about artistic achievement and primarily seeks popularity and commerciality:

The MIJI songs were created with the aim of better communication with the masses. They do sound familiar, however, they irritate since they resemble popular songs too much. [...] Bent solely upon popularity, they seem to have lost their identity. It is like they sold their spirit to the devil, blind with gaining popularity. [...] In the MIJI album The Challenge there is no intention to 
compete with the contemporary popular music; but their purpose is in fact to join them. (Hahn 2010)

He continues that, "in the MIJI album The Challenge, there is no ambition to popularize traditional gugak but only a sales gimmick to make the group known" (ibid). According to him, fusing gugak with Korean popular songs is not a challenging job but is rather an easy way for the musicians to join the arena of popular music. To him, the first priority of fusion gugak should be creativity based on authentic gugak. Fusion gugak should keep the identity of gugak as different from popular music and should have artistic value as an art piece as well.

Hahn's criticism of the music of MIJI represents the narratives in Korea on traditional gugak as one of several pure or authentic indigenous forms and as an invaluable asset to be preserved from foreign influence (Sutton 2011: 5). Sutton points out that in Korea, fusion gugak tends to be considered a problematic product that greys out cultural purity. In this type of discourse, the musicians of fusion gugak are not expected to follow or copy commercially oriented popular songs. Instead, they are expected to have an artistic and even national duty not only to spread an appreciation of gugak but also to creatively move beyond traditional gugak (Sutton 2009: 40). Park Seung-won (2011) ignored criticism of those like Hahn Dong-yun, leading MIJI to join the popular music industry. First, he categorized MIJI's first album The Challenge as gayo ("popular song"), not as gugak. It sold about 3,000 CDs in the first six months, while the Sookmyung Gayageum Orchestra, which dominated gugak bestselling charts, sold less than 300 for the same period in their debut back in 1994, according to Park, who worked for production and distribution of both. Additionally, in March $2011 \mathrm{MIJ}$ released a music video of their digital single Unbelievable, a combination of Korean pop song and R\&B featuring a guest appearance of the hallyu star Kim Jin Ho from K-pop group SG Wannabe.

The MIJI group used the mass media to promote their work. The TV programs in which MIJI appeared include Nollaun Daehoe! Star King ("Star King", 6 February 2009) of SBS; Gayo Daejejeon ("Great Show of Pop Music", 31 December 2009); Show! Eumak Jungsim ("Show! Music Center", 30 January 2010) of MBC; Music Bank (29 January 2010) of KBS; and The M (24 and 27 January 2010) of MTV. MIJI appeared on music programs and talk shows just like Girls' Generation, ${ }^{7}$ a popular female K-pop group, had done. Though MIJI could have used Gugak FM (a radio station sponsored by the Ministry of Culture, Sports and Tourism dedicated to the broadcast of gugak) the group preferred network TV over both cable TV and radio $^{8}$ because network TV has higher viewer ratings. People seeking to make themselves widely known often place priority on TV over radio as MIJI did.

To attract TV viewers, the MIJI members were encouraged to present a "classy" and "sexy look", similar to the popular stars that viewers are used to, and for a period things went well for MIJI: Jo Young-soo's composition "Heunoni", a song from their first album, was ranked within the Top Ten for a week on the MelOn website (2011). MIJI was selected to perform the music for the documentary $A$ Journey in Search of Korea's Beauty (2011) produced by Bae Yong Joon, who had played the lead in Winter Sonata. MIJI was also chosen to play the music for the original sound track of Sin Gisaengjeon ("New Tales of Female Entertainers"), a 
TV drama with a viewer rating of 28.3 percent (Naver 2011). Park Seung-won attributes the MIJI's success in working with popular programs on mass broadcast media to the fact that the group had appeared in many network TV shows with high viewer ratings.

MIJI was labeled the "Korean Equivalent to 12-Girls Band", which refers to a Chinese pop-traditional fusion instrumental music ensemble, in one of Korea's major journals (Shin 2010). Park Seung-won (2011) says that, "when he launched the MIJI project, he benchmarked the Chinese 12-Girls Band". He turned MIJI into an act that was different from the Chinese music group, whose members are all instrumentalists, by adding a singer to the group, allowing the group to perform songs similar to other hallyu music groups. KBS World (2010) explicitly linked MIJI and other similar gugak fusion groups to pop music girl groups, saying that "amid the renaissance of girl groups in the K-pop scene, they have transformed their image as the Girls' Generation, a K-pop female idol group, of the traditional music genre".

The project intended to turn MIJI into a successful model for popular gugak bands by 2011. However, in April 2011, before the band achieved this goal, the Ministry of Culture, Sports and Tourism decided to stop sponsoring MIJI. According to the Ministry's representative, Park Jeong-gyeong (2011), the Ministry evaluated the group's musical ability as being insufficient for continued support. Park Seung-won (2011) told me during our interview that he did not agree with the Ministry's decision; he insisted that "you should not judge the new gugak pop group members by the same standards that you use for the holders of Intangible Cultural Assets or venerable traditional gugak musicians". Park added to this that hardly any group succeeds with their first album.

MIJI earned no small fee for their work "as a gugak group"; however, it was not enough for each of the seven members and even less for the company. The group's income was not up to the standard of the pop music industry in Korea. Without the government's support, the company would not have started the project of managing the band. The LOEN company subsequently closed the division of gugak in December 2011. Park Seung-won quit the company and has since worked as a freelancer. According to him (2012), LOEN had a sixty percent national market share of gugak CDs in Korea before the closure of the gugak division. LOEN's departure from the gugak market with its large share signaled that even fewer gugak CDs would be available to the public.

In August 2011, MIJI was transferred to another company, Mask Entertainment, and the number of members was reduced to five; vocalist Kim Bo-seong left, having been scouted by a company named C3 Entertainment. The CEO of Mask Entertainment, Jeon Hye-joon, quit the company and established a new company, First Entertainment, in July 2012, which began to manage MIJI among others. During interview, Jeon (2013) explained that, "though the group was not profitable, I decided to manage the group because I believe that a popularlystyled gugak group should exist". Under the management of First Entertainment, MIJI entered the scene once again with an appearance on TV. In September 2012, MBC, one of Korea's major network TV channels, arranged a regular slot in a pop music show entitled Show! Eumak Jungsim ("Show! Music Center") for a gugak fusion group to play in collaboration with a popular music group. 
MIJI's appearance in Show! Eumak Jungsim was arranged by an MBC producer, Pang Seong-keun. Pang (2013) says that he had produced, out of sympathy for its lack of popularity, a few gugak programs in 1995 and 1996 with a patriotic motivation and an artistic interest in gugak. Those program series lasted only roughly one year due to low viewer ratings. ${ }^{9}$ Around twenty years later, when he came to hold a position as executive managing director of the entertainment division at MBC (controlling programming for the music shows), he ordered a young producer in charge of Show! Eumak Jungsim to arrange a regular slot for a gugak fusion group to play in collaboration with a popular music group. The Show! Eumak Jungsim is a long-running show, broadcast weekly since 2005. Pang found MIJI suitable for the program. The slot for MIJI lasted four months, during which popular music was rearranged for gugak instruments. However, Pang was not satisfied with the result, critically commenting that when MIJI played in collaboration with pop music groups, the MIJI members did not stand out; in short, they were unable to attract the audience with their own uniqueness.

Nevertheless, according to Jeon Hye-joon (2013), the current MIJI manager, the performances in the show made a positive effect on the group:

Through their collaboration work with popular musicians, the MIJI members familiarized themselves with popular music more than before. They came to enjoy themselves more when they were on the stage. However, it is still not easy to maintain the group because it is not profitable.

In February 2013 MIJI released their single entitled Oriental Blue with three songs by famous composers, including $\mathrm{Yu}$ Hae-jun, the composer of the main theme music for Winter Sonata. Then, as recently as August 2014, the group appeared in one of Asia's most popular entertainment programs, Star Avenue of CCTV (China Central Television), where such K-pop idol groups as Exo and Kara appeared. This gave them their chance to become known in China. As the first Korean gugak group appearing on Star Avenue, MIJI played music in collaboration with a Chinese female fusion group called Amethyst Band (NEWSis 2014). This might have been a chance for them to get one step closer to the individual members' dreams of joining K-pop.

The process involved in development of the MIJI project points out the existence of cultural producers, such as the band managers Park Seung-won and Jeon Hye-joon, and the radio producer Pang Seong-keun, each who have both a patriotic and artistic motivation in their efforts to popularize gugak. It is different from the image that tradition purists have of people in the pop music industry as people motivated by commercial greed (Edensor 2002: 22). While the commercially oriented management company stopped managing the team, Jeon Hye-joon (2013) said that he would not leave MIJI, which still has a long way in its struggle for popularization of gugak.

\section{A dilemma in popularization of gugak}

Although largely ignored by the general public since the beginning of Korea's Westernization and industrialization, gugak is slowly increasing in popularity. 
With efforts by some cultural producers and government officials to incorporate gugak into the mainstream, a gugak department in the college of music in Seoul National University was established in 1959. Being part of the curriculum of the most renowned academic institute in Korea improved gugak's image.

In the 1990s, with the Korean economy strengthening and with society diversifying, to people searching for something new, gugak, along with Korean traditional breathing or meditation, became an alternative to the contemporary culture, which was largely Western. In 1993, the film Seopyeonje depicted a family of pansori (epic narrative song) musicians. The movie became a historical landmark when it set a new record at the box office. It was seen by more than one million people within six months of its opening (Willoughby 2003: 119). The following year, 1994, was designated by the Korean government as the "Year of gugak". The "Year of gugak" campaign succeeded in sparking people's consciousness of gugak by increasing its exposure. For example, four times more gugak performances were held this year than in the previous year. However, these projects, such as those using gugak in national ceremonies and in school activities, failed to bring gugak into everyday life and to sustain or even increase people's interest in gugak, which was the whole point of the campaign (Kim 1994).

Gugak was gaining more attention from an increased number of people, but still not sufficiently from the general public. The different types of gugak, from court music to folk, came to be regarded as high culture, under the protection of the government, rather than as the low culture of the majority; ironically, before the introduction of Western music to Korea, gugak was the only music (Edensor 2002: 5). None of the forms of gugak are yet commercially viable. According to Jung Chang-kwan's gugak website (gugakcd.kr 2012), about 230 gugak CDs were released in 2011 in Korea, but sales were much weaker than globally styled pop music CDs. Park Seung-won (2011) says that "for every gugak CD sold, 200 CDs of popular music are sold. This ratio excludes other types of music, such as Western classical". Statistics show that the gap between CD sales of gugak and that of popular music is even bigger than the ratio Park had mentioned; in 2010, sales of the top one hundred gugak CDs amounted to 27,430, while sales of the top ten popular music CD reached 1,373,419 (Korea Creative Content Agency 2012; the Ministry of Culture, Sports and Tourism 2011: 29).

Fusion gugak, with its elements of Western classical and popular music, sells better than traditional gugak. According to a survey by the Ministry of Culture, Sports, and Tourism (2008: 63), the bestselling album from 2008 through 2010 was not a CD of traditional gugak but of fusion gugak. It was For YOU: Best Collection 2006 by the Sookmyung Gayageum Orchestra. The CD contains arrangements of well-known popular and folk tunes for modified 25-stringed gayageum..$^{10}$

The next important issue is: who are the players of fusion gugak? They are mostly graduates from gugak schools most of whom focused on traditional gugak. Many of them choose to play fusion gugak, crossing the boundaries of the repertoire of the traditional music, out of musical interest, so that their instrument does not remain as something for the museum only but for everyday life. Still, others pick it up as a second choice. According to Kim Su-jin (2011), a survey by Busan National University carried out in 2011 showed that 81 out of 112 students 
were considering becoming fusion gugak musicians based on economic considerations since one can hardly make a living by playing "traditional" (nonfusion) gugak unless one belongs to a government-funded public or private gugak orchestra. Approximately 1,000 musicians graduate universities majoring in gugak every year in Korea and there are about 180 active gugak fusion groups.

One would expect such artists to have the same attitude about their career in music as popular musicians do, but, as mentioned previously, gugak musicians, including those in MIJI, tend to be more patriotically motivated than commercially oriented. Kim Bo-seong (2011), the former vocalist of MIJI, stated during our interview that

some people might think that I earned money from the gugak activities in the popular culture industry. In reality, I am paid only a small amount of money. I do not this for money. My motivation is the popularization and promotion of gugak.

As can be seen in the comment of Kim Bo-seong, who had originally dreamt of joining a K-pop group, there are echoes of nationalism contradictory to the goals of commercially oriented music. In the mind of young fusion gugak musicians, gugak is not something that can be turned into a commercial advantage, bought and sold (Taylor 2007: 281).

In terms of feelings for the traditional music of their country, young gugak musicians are different from the average youth of Korea, the main consumers and performers of pop culture here. Jim Dator and Yongseok Seo (2004: 39) described the average youth as

cynical about nationalistic perspectives of the older cohorts regarding pop culture and Hanryu [hallyu] and their peers make up the majority of the performers. [...] For them nationality and the origin of a cultural product are not important as long as they are satisfied with the sensitivities and emotions, and there is no such thing as a cultural periphery inferiority complex.

Park Seung-won (2011) criticized MIJI members and gugak musicians in general, not for their musical abilities but for their passive attitudes to popular music.
Most gugak artists differ from those in popular music as they tend to be treated as "artists" in contrast to pop singers who admit that their life as pop stars depends on popularity with the masses, and to pursue this end they will do whatever necessary to gain popular following, even changing themselves again and again to meet the demands of the populace. Gugak musicians pander less than pop musicians in pursuing this goal of being popular, which weakens their competitiveness in the world of popular music in Korea.

Similarly, Pang Seong-keun (2013), the MBC producer, criticized that, "gugak musicians tend to be self-content with their own music which they stick to conservatively". What makes gugak musicians patriotic, conservative and less aggressive in pursuing their goal? Yang Hyo-sook, a member-musician of the National Namwon Gugak Center, comments in my interview with her (2011): 
Most gugak musicians have a tendency to be spoiled like children who grow up over-protected. Gugak musicians of the older generation tend to teach young ones to be proud of being artists of high culture, whereas in the past they were looked down upon and found it difficult to feel proud of themselves. By promoting pride in the younger generation, they are able to compensate for their past inferiority complexes. One effect on the young gugak musicians is that they become too proud of being "national artists" to have a healthy sense of modesty.

Yang notes that the protection of the government works like a green house where young gugak musicians grow away from the real world; their growing process as the present national artists is deeply influenced by their masters, each who had inferiority complexes about the past. So the young apprentice gugak musicians have a tendency to combine with gugak the memory of the poverty or hunger of the old gugak master, while the average young music consumer, with no such memory of poverty or hunger, explores the new world of pop culture beyond limits (Dator and Seo 2004: 32-33).

In this environment where young gugak musicians do not have a chance to be exposed to the real life of the music industry and its market, they are ignorant about the rather complex nature of popular music. Contrasting Blacking's opinion that "popular music is nothing but music that is admired by people in general" (Blacking 1981: 13), popular music is a fluid mix of Western and Japanese influences, one that gugak students have not been introduced to in the university gugak departments (Yun 2008). Kim Dae-jin (2012), director of the project division at the Korean Traditional Performing Arts Foundation who worked on the MIJI project with LOEN and the Ministry of Culture, Sports, and Tourism, adds that

It will not be easy for young gugak musicians to succeed in the popular music industry since they have lived in the small world of gugak like plants in a green house. They do not have experience enough to prepare them for living in the tough world of music industry and market.

According to Yang, Yun, and Kim, the influences on gugak musicians' attitudes are rather complex and sophisticated. Whereas the musicians of popular music focus purely on the artists and the entertainment aspect of music, gugak musicians additionally consider social elements. They bear in mind the unique historical and social issues of gugak, which in colonial period was lower than that of the currently dominant Western style of music. Further, they are conscious of the fact that gugak has come to be protected and promoted by the government as a symbol of national identity in the post-colonial period.

There is an opinion that gugak musicians need to be more creative and imaginative, and to overcome the problems caused by the elitist circle of the gugak community by breaking down the wall between gugak and popular music. Park Seung-won (2011) advises that, "gugak musicians, in order to be successful, need to consider the demands and needs of the masses with their varying tastes" (Lang and Engel Lang 2009: 1017). 
This brings forth the issue of the various roles of the government in the popularization of gugak, including the Star project connecting gugak and popular music industry, education, and mass media.

\section{Role of the government in the popularization of gugak and education}

Nettl (1983: 299) argues that governments tend to regard themselves as the owner of the culture's music, a commodity that can be controlled, and the Korean government's attempts to manage gugak is not unique. Furthermore, such cultural support and protectionism is not a new phenomenon. For example, throughout the dynasties of China up to the twentieth century, many types of music were state-sponsored and supervised as an ideological issue (Yang and Saffle 2010: 97). In Korea, music has long been managed by national institutes, such as Jangakwon (Royal Music Institute) of the Joseon Dynasty (1392-1910).

In the twenty-first century the Korean government initiated the Star (or MIJI) project as a way of building upon the Korean wave through the promotion of contemporary traditional culture. This became an issue. The government's support for MIJI was controversial and far from unanimously approved. Researcher Park Jeong-gyeong (2011) says that, "the support for the Star project was viewed as favoring a specific group". The government supported MIJI for three years, from 2008 to 2010. Three years of government support for one group was considered excessive when there were about 630 traditional performing arts groups in Korea, all in need of support (Korean Ministry of Culture, Sports and Tourism 2011: 6). Actually, though, the support was too short for MIJI to achieve their ultimate goal. The MIJI project was not about promoting the activities of one existing group; rather, from the very beginning it was about the formation of a new group by involving the training of the inexperienced performers. Considering the fact that the selection of the MIJI members, including the vocalist, was completed only in October 2009 and the first CD was released in December 2009, MIJI's real activity with the support of the government and the management of the LOEN company amounted to only about one year (as opposed to the planned three years) which is too short to guarantee a successful debut in the pop music industry.

It is difficult to predict whether a group will ever acquire star status in popular music or not. Tim Edensor (2002: 14) says that,

[...] rather than a conspiratorial science where producers plot how to conquer markets by persuading the masses to consume their products, making and marketing culture is an inexact science. For instance, record companies are unable to second-guess the tastes of consumers, as is indicated by the numerous failed investments which are made in unsuccessful artists and musical products. The "hit record" remains an elusive prize.

This project, which in its nature was likely to need longevity to reach its goal, was evaluated every year by the government since it received funding. Considering it 
is a government funded project, logic would compel evaluation every fiscal year no matter how long it may take to achieve its goal, which, in the case of MIJI, is to reach stardom. In my interview with Kim Dae-jin (2011), he said that, "when the government is involved, the bureaucratic process tends to become an issue". According to him, when things move fast, as in the pop music industry, the delay caused by bureaucratic processes may become a hindrance to the project. Government bureaucracy and the nature of popular music projects tend to be at variance with each other.

Among all the controversy and contradiction, one thing for certain is that the band MIJI still survives and is developing from its foundation as a relatively short government support project under the short but strategic management of LOEN company. There are many other teams in need of the same kind of support. Therefore, as an alternative, Song Hye-jin (2012), the Director of Sookmyung Gayageum Orchestra, suggests that the government should avoid selecting one single group, partner specialist, or company, as in the case of MIJI, and to develop projects connecting gugak musicians with pop music industry specialists. In this way, Song suggests that the government will be able to give a number of groups and specialists equal and open chances to meet each other and work in collaboration in the long term.

There is another measure, a long-term measure, which the government could take to popularize gugak. This would be the education of a potential audience and consumers of the commodity of gugak. Although the government gradually increased gugak songs in primary school music textbooks, it turns out that most teachers do not teach the songs since they had not learned those songs when they were young and, thus, do not feel confident about their own performance of gugak. Currently, most music teachers have majored in Western classical music in school. They are in the majority, while teachers who have majored in gugak are rare. So, though the government has taken many different educational measures to promote gugak, these measures have not worked well. According to Lee Inwon, director of the Korean Gugak Education Institute, there are those in the gugak community that say that the government should make a rule to hire more people with a background in gugak as music teachers (Lee 2008).

The last but not least important long-term measure the government could take is in the area of mass media. According to Blumer (1985: 12), mass media are powerful tools in approaching the populace, particularly those consisting of individuals from a heterogeneous background. The Korean government has used mass media for popularization of gugak, for example through its establishment of Gugak FM in 2001. However, according to Chae Chi-seong (2013), CEO of Gugak FM, most producers that work in network TV and radio do not feel any obligation to play gugak since it has low viewer ratings. Therefore, Pang Seongkeun (2013) insists that, "to popularize gugak, government should require a specific amount of exposure of gugak to be broadcast on TV and radio". Then, gugak programming on the main channels of TV and radio will give more opportunity to gugak musicians to make themselves known to the public, and this, in turn, would help the public to familiarize themselves with gugak. 


\section{Conclusion}

The unpopularity of gugak among the Korean people is mainly a consequence of the prioritization of Western music in schools and its wide availability in mass media. This is not to say that people and institutions related to gugak, including government, schools, and mass media, have ignored gugak. On the contrary, the government, in particular, has played an important role in at least the preservation of gugak through favorable cultural policies. Nevertheless, its popularity still lags behind that of Western-style pop music. The government realized this and, when it saw that Korea's traditional culture was rediscovered globally, supported the gugak group MIJI through its Star project in order to support gugak and its musicians more actively.

This case study of the government-initiated MIJI project shows that the present situation of gugak musicians is a tug of war between old and new and between traditional and popular music culture. We also see that, among the average youth of contemporary Korea, there is less attachment to their ethnic heritage. Having suffered through the government's increased but still inadequate support and its bureaucratic interference, along with the confounding ways of the pop music industry, MIJI struggles on, under the leadership of just one single cultural producer striving for the popularization of gugak.

In the long run, MIJI may or may not become more popular. MIJI is just one of several young gugak groups that combine gugak with popular music. There are many other active groups currently that have creativity and individuality, and the spectrum of gugak groups is widening. However, with gugak's many years of estrangement from the general audience in Korea, it will take more time before the tensions between gugak and other agents of our music culture are resolved and a possible "new unity" is achieved (Kartomi 1995: 245). Gugak must find a way to deal with its limited commercial viability and with uneven government support to make it viable.

\section{Acknowledgements}

I wish to express my appreciation to MIJI's former manager, Park Seung-won, and present manager, Jeon Hye-joon, for sharing their knowledge and experience and allowing the use of a publicity photo of MIJI. I am grateful to my interviewees for giving permission to cite identifiable extracts from the interviews that were conducted as part of the research towards this publication. I also thank the MBC producer, Pang Seong-keun, the Korean Traditional Performing Arts Foundation Projects Division Director, Kim Dae-jin, and Professors John Holstein, Roald Maliangkay, and Ruth Mueller for their helpful comments.

\section{Endnotes}

${ }^{1}$ The first Republic of Korea (1948-1960), headed by president Rhee Syngman, stressed national culture as an essential element in state policy. In the regime that followed, under president Park Chung Hee (1961-1979), traditional performing arts were specifically included, a policy that continues to this day. 
2 "HanStyle" was coined by the Korean government, combining "Han" (Korea) and "Style" (manners or rules). The word embraces Korean traditional culture as a source of Korean culture today.

${ }^{3}$ The Star project was a part of a larger project of the Korea Ministry of Culture, Sports, and Tourism entitled Creating Digital Contents of Korean Traditional Arts. There was no Star project before MIJI.

${ }^{4}$ Gong Myoung, meaning "resonance" in English, consists of four men. The band has been playing its own creations, mostly using percussion and wind instruments made of bamboo, since its formation in 1997.

${ }^{5}$ Sangsang is a soloist ensemble consisting of three string players on gayageum, haegeum, and geomungo, who have played together since 2000. The three high school classmates create their music themselves and improvise while playing.

${ }^{6}$ The original English title of "Ibyeorae" on the CD is "My Farewell Comfort". However, "Farewell Hill" would be the correct direct translation of ibyeorae.

${ }^{7}$ Girls' Generation (Sonyeo Sidae in Korean) was formed by SM Entertainment in 2007. SM Entertainment was launched by Lee Soo-man, who played a major role in the production of K-pop hits worldwide. It was one of the most popular girl groups at the time, not only in Korea but also in other Asian countries, including Japan and Vietnam. In 2012, the act also appeared on American TV talk shows, such as CBS's Late Show with David Letterman and Live with Kelly.

${ }^{8}$ According to Chae Chi-seong, CEO of Gugak FM, the average listening rate for Gugak FM was about 2.0 percent in 2013.

${ }^{9}$ Pang Seong-keun had produced a program titled Saemi Gipeun Mul ("Water in Deep Pond"), which focuses on the harmony of gugak, popular music and Western classical music. The program started in September 1995; however, in October 1996, roughly one year later, the program was stopped because it was too hard to sell advertising space due to the limited viewer ratings. In 1996 he produced another show, Cheongsonyeon Eumakhoe ("Youth Concert"), which had the same difficulty of low viewer ratings, and the same fatal consequences.

${ }^{10}$ There are thirteen pieces in the album: four Beatles' songs, such as "Let it Be" and "Hey Jude"; two Russian songs ("The Amur's Waves" and "Katyusha"); a Cuban popular song ("Quizas Quizas Quizas"); the movement "Winter" from Vivaldi's Four Seasons; two new arrangements of gugak folk songs ("Arirang" and "Doraji"), and one new arrangement of a piece by a North Korean composer, "Chosoeui bom" ("Spring at the Guardpost"). The musical focus of the CD is not on the gugak tunes but the popular "old" Western tunes such as "Let it Be". This CD's "Let it Be" was selected as a theme tune on KTX (Korea Train Express). It shows that the combination of the familiarity of old non-Korean tunes

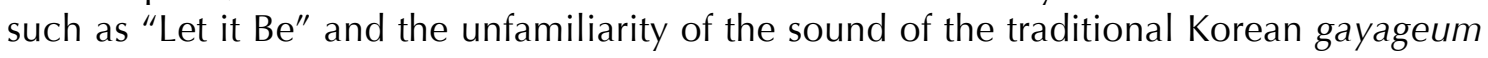
attracts Korean people.

\section{References}

\section{Bibliography}

Bhabha, H. K. 1994. Location of Culture. New York: Routledge. 
Blacking, J. 1981. Making Artistic Popular Music: the Goal of True Folk. Popular Music 1: 9-14.

Blumer, H. 1985. Moulding of Mass Behaviour through the Motion Picture. Publication of the American Sociological Society 9 (3): 115-127.

Dator, J. and Seo, Yongseok 2004. Korea as the Wave of a Future: The Emerging Dream Society of Icons and Aesthetic Experience. Journal of Future Studies 9 (1), August: 31-44.

Edensor, T. 2002. National Identity, Popular Culture and Everyday Life. Oxford \& New York: Berg.

Hahn, Dong-yun. 2010. MIJI, Sangsulro Mandeun Fusion Gugak ("Fusion Gugak Made in Commercialism"). 19 January. http://soulounge.egloos.com/2822021; Accessed: 28 December 2011.

Howard, K. 2008. Strategies for the Globalization of Korean Traditional Music. The Korean Ministry of Culture, Sports and Tourism, International Conference of Korean Musicologists, Busan National Gugak Center: Busan, 4-7 November 2008.

Im, Sang-beom. 2012. Traditional Korean Music Marches Forward. KOREA 8 (5), May: 30-31.

Jung, Chang-kwan. 2012. Gugak CD Eumban Chulpan Hyeonhwang ("Status of Current Gugak CD Releases"). www.gugakcd.kr/publish.htm; Accessed: 13 October 2012.

Kartomi, M. J. -

1981. The Processes and Results of Musical Culture Contact. A Discussion of

Terminology and Concepts. Ethnomusicology 25 (2): 227-249.

1995. "Traditional Music Weeps" and Other Themes in the Discourse on

Music, Dance and Theater of Indonesia, Malaysia and Thailand. Journal of

Southeast Asian Studies 26 (2): 366-400.

KBS World. 2010. Culture on the Move, Girl Groups in the Spotlight in the Traditional Music Scene. 31 March.

http://rki.kbs.co.kr/english/archive/culturenlife realfield.htm?no=2001\&current page=; Accessed: 28 December 2011.

Kim, So-jin. 1994. Jindan '94 Gugakeui Hae ("Evaluation of the 1994 Year of Gugak Campaign"). The Hankyoreh, 3 December.

http://newslibrary.naver.com/viewer/index.nhn?articleld=19941203002891090 13\&editNo=5\&printCount=1 \&publishDate=1994-12-

$03 \&$ officeld=00028\&pageNo=9\&print $\mathrm{No}=2084 \&$ publishType=00010;

Accessed: 12 February 2015.

Kim, Su-jin. 2011. The Korea National Open University Weekly. 20 June. http://news.knou.ac.kr/news/article.html?no=23233; Accessed: 16 October 2012.

Korea Creative Content Agency. 2012. Music Industry White Paper. http://www.kocca.kr/cop/bbs/view/B0000146/1821713.do?searchCnd=\&search Wrd $=\&$ cateTp $1=\&$ cateTp $2=\&$ useAt $=\&$ menuNo $=201826 \&$ categorys $=0 \&$ subcate $=0 \&$ cateCode $=\&$ type $=\&$ inst $\mathrm{No}=0 \&$ questionTp $=\&$ uf_Setting $=\&$ recovery $=\&$ pagel ndex=4; Accessed: 2 Februrary 2015.

Lang, K. and Engel Lang, G. 2009. Mass Society, Mass Culture, and Mass Communication: The Meanings of Mass. International Journal of Communication 3: 998-1024. 
Lee, Haewon. 2014. Gugakgeurup MIJI, Jungguk Seongkwangdaedo Chulyeon 13eok Junggukingwa Jou ("Gugak girl group MIJI meets with 1.3 million Chinese on Star Avenue"). 4 August. 2014.http://m.news.naver.com/read.nhn?mode=SD\&mid=sec\&sid1=103\&oid= 057\&aid=0000421677; Accessed: 31 August 2014.

Lee, Inwon. 2008. Gugakgyoyuk Hanbeon Jedaero Sikkyeo Bopssida ("Let us provide proper gugak education") http://www.hanstyle.com/hanstyle/specialist/specialview.jsp?def=\&seq=126\&pageNum=4\&pag eSize $=10 \&$ search=\&keyword=\&strCate=; Accessed: 16 October 2012.

Lee, So Young. 2003. Reading New Music in the Age of Fusion Culture. Tongyang Umak (Journal of Asian Music Research Institute) 25: 189-226.

LOEN Entertainment 2009. Who is MIJI. (publicity material). 2011. www.iloen.com; Accessed: 28 December 2011.

MelOn 2011. http://www.melon.com/chart/index.htm; Accessed: 21 March 2011. Naver 2011. TV program jeongbo ("TV Program Information"). 17 July. http://search.naver.com/search.naver?where $=$ nexearch\&query $=\% \mathrm{EC} \% 8 \mathrm{~B} \% \mathrm{A0}$ $\%$ EA\%B8\%B0\%EC\%83\%9D\%EC\%A0\%84+\%EC\%8B\%9C\%EC\%B2\%AD\%EB \%A5\%A0\&sm=top_hty\&fbm=1\&ie=utf8; Accessed: 26 May 2012.

NEWSis. 2014. Gugak Girl Group MIJI, Junggukeseo Oraeyo... Exo, Kara Geup ("Gugak girl group MIJI invited by China's CCTV just like Exo and Kara"). 4 August 2012. http://m.news.naver.com/read.nhn?mode=SD\&mid=sec\&sid1=106\&oid=003\& aid=00005923618; Accessed: 31 August 2014.

Nettl, B. Ed. 1983. The Study of Ethnomusicology, Twenty-nine Issues and Concepts. The Study of Music in Culture. Urbana: University of Illinois Press.

Shin, Yong-ho. 2010. Korean Equivalent to 12 Girls Band. Korean Joongang Daily, 20 January. http://joongangdaily.joins.com/article/view.asp?aid=2915503; Accessed: 28 December 2011.

So, Inhwa. 2008. Mediating Tradition: Issues in the Broadcasting of Korean Traditional Music. In Yi Young-shik, Shin Eun-ju and Kim Se-jung Eds. Essays on Music Offered to Dr. Lee Hye-ku in Honor of his Hundredth Birthday. Seoul: Hangukgukakhakhoe (Korean Musicological Society): 903-917.

Sung, H. F. 2009. Image Is Everything: Re-imaging Traditional Music in the Era of the Korean Wave. Southeast Review of Asian Studies 31: 39-55.

Sutton, R. A. 2009. Korean Fusion Music on the World Stage: Perspectives on the Aesthetics of Hybridity. Acta Koreana 12 (1): 27-52.

2011. Fusion and Questions of Korean Cultural Identity in Music. The Korean Studies Journal 35: 4-24.

Taylor, T. D. 2007. The Commodification of Music at the Dawn of the Era of "Mechanical Music". Ethnomusicology 51 (2): 281-305.

The Korean Ministry of Culture, Sports and Tourism. 2008. Munhwajeongchaekbaekseo ("White Paper on Cultural Policy"). 2011. 2010 Jeontong Gongyeonyesul Tonggyejosa ("2010 Statistical Survey of Korean Traditional Performing Arts").

Um, Hae-kyung. 2008. Locating Korean Music in the Age of Globalization. The Korean Ministry of Culture, Sports and Tourism, International Conference of 
Korean Musicologists, Busan National Gugak Center: Busan, 4-7 November 2008.

Willoughby, H. A. 2003. Retake: A Decade of Learning from the Movie Sóp'yónje. Music and Culture 8: 119-143.

Yang, Hon-Lun and Saffe, M. 2010. The 12 Girls Band: Traditions, Gender, Globalization, and (Inter)national Identity. Asian Music 41 (2): 88-112.

Yim, Haksoon. 2002. Cultural Identity and Cultural Policy in South Korea. The International Journal of Cultural Policy 8 (1): 37-48.

Yun, Chung-gang. 2008. Hangukjeontongeumakkwa Daejunmunhwa ("Korean Traditional Music and Pop Culture") http://www.hanstyle.com/hankukak/specialist/specialview.jsp?def=\&seq=43\&pageNum=2\&pag eSize=10\&search=\&keyword=\&strCate=H6; Accessed: 28 December 2011 .

\section{Discography}

Gugak FM Broadcasting System. 2012. Sinnyeon Teukjipjwadamhoe, K-popgwa Gugaksai ("Talk Show New Year Special: Between K-pop and Gugak"). 4 January. http://www.gugakfm.co.kr/gugak_web/Player/SpecialRadio_listen.jsp; Accessed: 16 October 2012.

MIJI -

2009. The Challenge, 14 January, LOEN, Korea.

2011. Unbelievable, 25 March, LOEN, Korea.

Sookmyung Gayageum Orchestra. 2006. For YOU: Best Collection 2006, 16 May, Seoul Records, Korea.

\section{Videography}

A Journey in Search of Korea's Beauty. 2011. Prod. Bae Yong Joon. DVD. Loen Entertainment.

MIII Arirang (Korean Traditional Folk Song). 2010. Youtube.com. 10 November. http://www.youtube.com/watch?v=maPp7JuuLcl; Accessed: 21 September 2012.

MIJI Don't Cry (Heunoni). 2010. Youtube.com. 15 June. http://www.youtube.com/watch?v=ZGmMgJRkxSQ; Accessed: 21 September 2012.

MIII Fly Me to the Moon. 2010. Youtube.com. 2 September.

http://www.youtube.com/watch?v=9gpHVIIQcAk; Accessed: 16 October 2012.

Miji \& Kim Jin Ho (SG Wannabe) Unbelievable [New Digital Single]. 2011. Youtube.com. 24 March. http://www.youtube.com/watch?v=0JGv_zRg6gA; Accessed: 21 September 2012.

MIJI K. New. 2010. Youtube.com. 14 April.

http://www.youtube.com/watch?v=TsDOHvvc2T4; Accessed: 21 September 2012.

MIJI PROMOTION.wmv. 2009. Youtube.com. 31 December. http://www.youtube.com/watch?v=Kvc3BiUNXQ; Accessed: 21 September 2012. 
MIJI The Chaser. 2010. Youtube.com. 19 April.

http://www.youtube.com/watch?v=VPNhDnS5zZY; Accessed: 16 October 2012.

MIJI Unbelievable MV. 2010. Youtube.com. 24 March. http://www.youtube.com/watch?v=PzYffON8vXE; Accessed: 21 September 2012.

Seopyeonje. 1993. Dir. Kwon-taek Im. DVD. Spectrum DVD.

Traditional music group MIII [The NEXT HIT]. 2011. Youtube.com. 2 May.

http://www.youtube.com/watch?v=tJEg-ljdYgE; Accessed: 21 September 2012.

\section{Interviews}

Chae Chi-seong. 2013. Interviewed by the author, email, 13 March.

Jeon Hye-joon. 2013. Interviewed by the author, email, 14 February.

Kim Bo-seong. 2011. Interviewed by the author, email, 14 December.

Kim Dae-jin. 2012. Interviewed by the author, email, 14 March.

Pang Seong-keun. 2013. Interviewed by the author, email, 11 March.

Park Jeong-gyeong. 2011. Interviewed by the author, email, 11 July.

Park Seung-won -

2011. Interviewed by the author, email, 25 May.

2012. Interviewed by the author, email, 17 September.

Song Hye-jin. 2012. Interviewed by the author, email, 29 February.

Yang Hyo-sook. 2011. Interviewed by the author, email, 20 August. 